\section{Prenatal detection of orofacial clefts}

Orofacial clefts are one of the most common congenital anomalies. The incidence is approximately $1: 500$ to $1: 550$ births [1]. The group of orofacial anomalies is heterogeneous. It comprises "typical" orofacial clefts ((cleft lip (CL), cleft lip and cleft palate (CLP) and cleft palate only (CP)) and "atypical" clefts (median, transversal, oblique and other Tessier's types of facial clefts)[1]. The Tessier classification is an internationally accepted anatomical classification system that assigns a number to each cleft on the basis of its position relative to the sagittal midline [2]. An embryological-based classification was published by Mazzola $\mathrm{R}$ and Mazzola I [3].

The etiology of $C L \pm P$ is mostly unknown, but both genetic and environmental factors play a role [4]. A marked racial and geographic variability can be observed, with a high incidence in Asians, low in Blacks and intermediate in Whites [5].

Both typical and atypical clefts can occur as an isolated anomaly, as part of a sequence of the primary defect, or as a multiple congenital anomaly (MCA). In MCA, the cleft anomaly could be part of a known monogenic syndrome, part of a chromosomal aberration, part of an association, or part of a complex of multiple congenital anomalies of unknown etiology [1]. More than 300 syndromes are associated with facial clefting, e.g. Van der Woude, Goldenhar, CHARGE, Stickler, Treacher-Collins, Nager and Miller syndromes [1, 6-8]. Orofacial clefts in chromosomal aberration occur with a prevalence of 0.155 per 1,000 births [1]. The most common chromosomal aberrations are Trisomy 13, Trisomy 18 and Trisomy $21[1,8]$.

The embryological development of the craniofacial structures is complex. The face is derived from 5 facial prominences that surround the future mouth namely the unpaired frontonasal process, the paired maxillary and the paired mandibular process [9, 10]. Any incomplete fusion results in a congenital facial cleft [9].

Anatomically the cleft lips and palates are divided into 2 main groups: 1. clefts of the upper lip and the anterior part of the maxilla with or without parts of the hard and soft palate 2. clefts concerning the hard and soft palate. Anterior clefts include CL, with or without cleft of the alveolar ridge of the maxilla, posterior clefts concern the secondary (posterior) palate and extend through the soft and hard palate to the Foramen incisivum [9]. Anterior and posterior clefts are different from the embryologic point of view. Cleft lips result when there is no fusion between the maxillary prominences and the medial nasal prominence. Cleft palate is found when there is no fusion between the two lateral palate prominences [9]. In median clefts a lack of mesenchyme is assumed to be responsable [9].

In the epidemiologic study of Doray et al. [8] CLs were unilateral in $79 \%$ of the cases $(60 / 76)$, bilateral in $20 \%$ of the cases $(15 / 76)$, and median in $1 \%(1 / 76) ; 55 \%$ of the unilateral CLs were right and $45 \%$ were left. CLPs were unilateral in $59 \%$ of the cases $(76 / 128)$, bilateral in $39 \%$ of the cases (50/128), and median in $2 \%(2 / 128)$; $45 \%$ of the unilateral CLPs were right and $55 \%$ were left.

\section{Pränatale Detektion von orofazialen Spalten}

Orofaziale Spaltbildungen gehören zu den häufigsten kongenitalen Fehlbildungen. Die Häufigkeit beträgt 1 : 500 bis $1: 550 \mathrm{Ge}-$ burten [1]. Die Gruppe der orofazialen Anomalien ist heterogen. Sie umfasst die „typischen“ orofazialen Spalten ((Lippenspalte (LS), Lippen-Kiefer-Gaumenspalte (LKGS) und Gaumenspalte (GS)) und die „atypischen“ Spalten (median, transversal, schräg und andere Tessier-Typen) [1]. Die Tessier-Klassifikation ist eine international anerkannte anatomische Klassifikation, bei der die einzelnen Gesichtsspalten anhand ihrer Position zur sagittalen Mittellinie nummeriert werden [2]. Eine Klassifikation nach embryologischen Gesichtspunkten wurde von Mazzola und Mazzola [3] publiziert.

Die Ätiologie von LS/LKGS ist weitgehend unbekannt, jedoch spielen genetische und umweltbedingte Faktoren eine Rolle [4]. Es gibt eine ausgeprägte Variabilität seitens der unterschiedlichen Rassen und der geografischen Lage. Die höchste Inzidenz findet man bei der asiatischen und die niedrigste bei der dunkelhäutige Bevölkerung, während die weiße Bevölkerung dazwischen liegt [5].

Sowohl die typischen als auch die atypischen Spalten werden als isolierte Anomalie, als Teil einer Fehlbildungssequenz oder im Rahmen einer multiplen kongenitalen Anomalie (MCA) gefunden. Bei MCA kann die Spaltbildung Teil eines bekannten monogenen Syndroms sein, Teil einer Chromosomenanomalie, einer Assoziation oder einer komplexen kongenitalen Fehlbildung unklarer Ätiologie [1]. Mehr als 300 Syndrome gehen mit Gesichtsspalten einher. Als Beispiele seien hier die nachfolgenden Syndrome aufgeführt: Van der Woude-, Goldenhar-, CHARGE-, Stickler-, Treacher-Collins-, Nager- und Miller-Syndrom [1, 6-8]. Orofaziale Spaltbildungen findet man bei Chromosomenstörungen mit einer Häufigkeit von 0,155 pro 1000 Geburten [1]. Als häufigste Chromosomenanomalien findet man Trisomie 13, Trisomie 18 und Trisomie $21[1,8]$.

Die embryologische Entwicklung der kraniofazialen Strukturen ist komplex. Das Gesicht entwickelt sich aus 5 verschiedenen Gesichtsfortsätzen, die den späteren Mund umgeben: der unpaare Stirnnasenfortsatz, die paarigen Oberkieferfortsätze und die paarigen Unterkieferfortsätze $[9,10]$. Jede unvollständige Verschmelzung der Gesichtsfortsätze führt zu einer kongenitalen Gesichtsspalte [9].

Bei den Lippen- und Gaumenspalten unterscheidet man 2 Hauptgruppen: 1 . Spalten der Oberlippe und des vorderen Teils der Maxilla mit oder ohne Beteiligung von Teilen des restlichen harten und weichen Gaumens und 2. Spalten, die den harten und den weichen Gaumen betreffen. Vordere Spalten schließen die Lippenspalte, mit oder ohne Spalte des alveolären Teils des Oberkiefers ein; hintere Spaltbildungen betreffen den sekundären (hinteren) Gaumen und erstrecken sich durch den weichen Gaumen und den harten Gaumen bis zum Foramen incisivum [9]. Vordere und hintere Spaltbildungen sind embryologisch verschieden. Während uni- und bilaterale Lippenspalten dadurch entstehen, dass die Oberkieferfortsätze und der mediale Nasenfortsatz nicht 


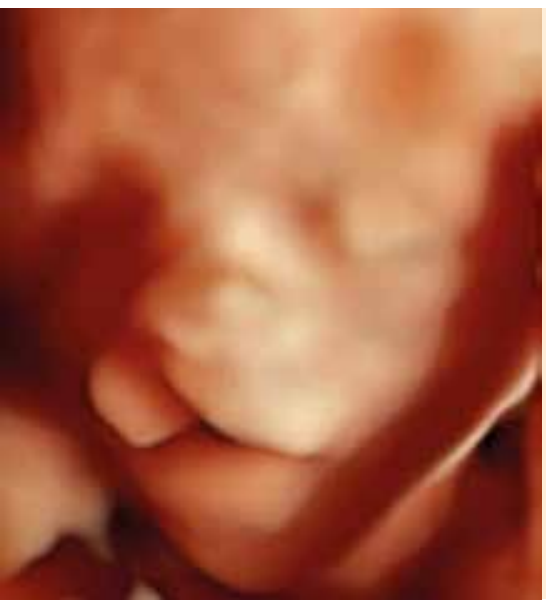

Fig. 1 HDlive surface rendering of a fetal face with unilateral cleft lip right (19 weeks' gestation). Abb. 1 HDlive-Oberfächenrendering eines fetalen Gesichts mit einer unilateralen rechtsseitigen Lippenspalte (19 Schwangerschaftswochen).

The prenatal diagnosis of CL/CLP is helpful in the preparation of the future parents regarding the first view of the defect in the newborn and in the early counceling of parents in regard to the correction possibilities of the defect by the face/oral surgeon as well.

Due to the high rate of underlying disease, the prenatal diagnosis of facial clefting will require a chromosomal analysis and a detailed anatomy scan to look for syndromes or non-syndromic malformations. In particular midline facial clefts are associated with brain anomalies resulting to a poor outcome in contrast to more favorable results in lateral clefts [11].

The demonstration of the fetal lips is part of a standard ultrasound examination in the second trimester malformation scan [12]. The detection rate of orofacial malformations depends on several factors: experience of the operator, ultrasound technology (2D, 3D ultrasound), position of the fetus and amount of amniotic fluid. In a systematic review of the literature Maarse et al. [13] found a considerable variety in the diagnostic accuracy of 2D ultrasound in the low-risk women, with prenatal detection rates ranging from 9 to $100 \%$ for cleft lip with or without cleft palate, 0 to $22 \%$ for cleft palate only and 0 to $73 \%$ for all types of cleft. 3D ultrasound in high-risk women resulted in a detection rate of 100 for cleft lip, 86 to $90 \%$ for cleft lip with palate and 0 to $89 \%$ for cleft palate only.

Despite the fact that the experienced operator is able to detect CL and CLP with 2D ultrasound [14] when the fetus is in a good position, the 2D demonstration of a facial defect is difficult to understand for the parents. In contrast to 2D ultrasound 3D ultrasound allows a detailed demonstration of the soft tissue of the fetal face, contributing to a better understanding of the malformation by the physician and the future parents. In particular HDlive technology [15] is now able to provide the operator and the parents with photorealistic pictures of a facial defect in the unborn ( $\bullet$ Fig. 1 and 2). Using surface rendered images of coronal cut planes we are also able to demonstrate isolated clefts in the hard and soft palate (๑ Fig. 3). However, 3-dimensional ultrasound is not only advantageous in surface rendering but also in the different 3D modes allowing a detailed assessment of the fetal face and the oral cavity. These modes include the triplanar mode that allows the simultaneous display of the 3 perpendicular planes (sagittal, axial and coronal) of the fetal face at the same time on the monitor ( $\bullet$ Fig. 3), the tomographic modus, showing parallel planes, and the transparency mode with the demonstra-

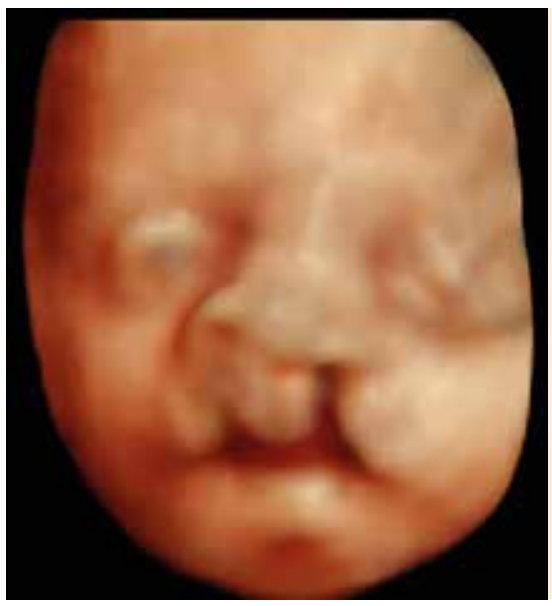

Fig. 2 HDlive surface rendering of a fetal face with bilateral cleft lip and palate (27 weeks' gestation).

Abb. 2 HDlive-Oberflächenrendering eines fetalen Gesichts mit einer bilateralen Lippen-Kiefer-Gaumenspalte $\quad(27$ Schwangerschaftswo-

chen).

miteinander verwachsen, entstehen Gaumenspalten dadurch, dass die beiden lateralen Gaumenfortsätze nicht miteinander verschmelzen. Bei den medialen Lippenspalten wird ein Mesenchymmangel im mittleren Anteil der Oberlippe angenommen [9].

In der epidemiologische Studie von Doray et al. (2012) zeigten sich unilaterale Lippenspalten in $79 \%$ der Fälle (60/76), bilaterale in $20 \%$ der Fälle (15/76), und mediane in 1\% der Fälle (1/76); 55\% der unilateralen Lippenspalten waren rechts, 45\% links. LKGSpalten waren unilateral in 59\% der Fälle (76/128), bilateral in $39 \%$ der Fälle (50/128), und median in 2\% der Fälle (2/128); 45\% der unilateralen LKG-Spalten waren rechts und 55\% links.

Die pränatale Diagnose einer Lippen-Kiefer-Gaumen-Spalte hilft sowohl bei der Vorbereitung der Eltern auf den Anblick des Defekts beim Neugeborenen als auch bei der frühzeitigen Beratung hinsichtlich der Korrekturmöglichkeiten durch den Gesichtsund Kieferchirurgen.

Aufgrund der hohen Rate von assoziierten Fehlbildungen u. Chromosomenaberrationen sollte bei jedem Nachweis einer fetalen Gesichtsspalte grundsätzlich nach weiteren fetalen Fehlbildungen (syndromale $u$. nicht syndromale) gesucht und auch der fetale Karyotyp abgeklärt werden. Insbesondere Mittelliniendefekte sind häufig mit Gehirnfehlbildungen und damit mit einer ungünstigen Prognose verbunden, während laterale Spalten eine deutlich bessere Prognose aufweisen [11].

Bei der fetalen Fehlbildungsdiagnostik gehört die Darstellung der fetalen Lippen zur sonografischen Standarduntersuchung im 2. Trimenon [12]. Die Entdeckungsrate von orofazialen Spaltbildungen hängt dabei nicht nur von der Erfahrung des Untersuchers und der dabei angewandten Ultraschalltechnik (2D-, 3D-Sonografie), sondern auch von der Lage des Feten und den Fruchtwasserverhältnissen $a b$. In einem systematischen Literaturreview fanden Maarse et al [13] eine betrachtliche Spannbreite in der diagnostischen Genauigkeit einer 2D-Ultraschalluntersuchung bei Low-risk-Patientinnen: die Detektionsraten lagen bei der Lippenspalte mit oder ohne Gaumenspalte zwischen 9 und $100 \%$, bei der alleinigen Gaumenspalte bei 0 bis $22 \%$ und bei allen Spalttypen bei 0 bis 73\%. 3D-Ultraschall führte bei High-risk-Patientinnen zu einer Entdeckungsrate von $100 \%$ bei den Lippenspalten, 86 bis $90 \%$ bei den Lippen-Kiefer-Gaumenspalten und 0 bis $89 \%$ bei den alleinigen Gaumenspalten. 


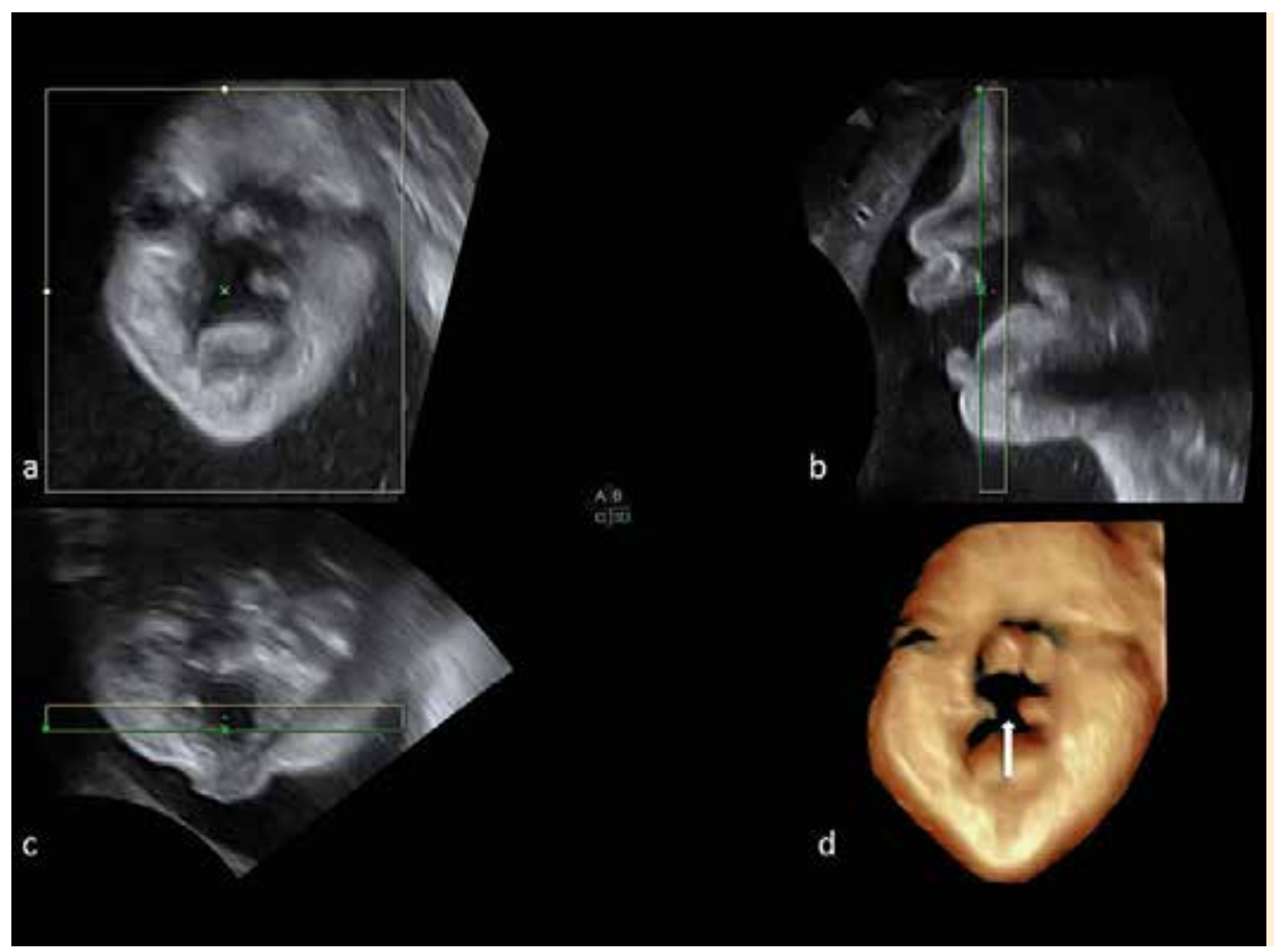

Fig. 3 Triplanar (a coronal. b sagittal, c axial plane) and surface demonstration (d) of an isolated cleft palate (34 weeks' gestation). The render box is set in that way that the rendered image shows a frontal surface picture of the coronal cut plane through the hard palate which reveals the bony defect $(\rightarrow)$. By scrolling the fetal head through the render box back and forth the entire palate can be controlled.

Abb. 3 Triplanare (a coronare. b sagittale, c axiale Ebene) und Oberflächendarstellung (d) einer isolierten Gaumenspalte (34 Schwangerschaftwochen). Die Renderbox ist derart platziert, dass man ein Oberflächenbild von der frontalen Schnittfläche durch den harten Gaumen bekommt und damit den knöchernen Defekt erkennt $(\rightarrow)$. Schiebt man den fetalen Kopf durch die Renderbox vor und zurück, so lässt sich der gesamte Gaumen kontrollieren.

tion of the bony structures of the fetal face only [16-20]. In particular the combination of the different 3D modes provides a detailed examination of the fetal face with a precise evaluation of forehead, orbits, eyes, nose, lips, alveolar ridge, chin, tongue and palate.

\section{E. Merz ${ }^{1}$, S. Pashaj ${ }^{1,2,},{ }^{1}$ Frankfurt/Germany, ${ }^{2}$ Tirana/Albania merz.eberhard@web.de}

References online
Obwohl der erfahrene Untersucher mit der 2D-Sonografie sowohl Lippen- als auch Lippen-Kiefer-Gaumenspalten nachweisen kann [14], wenn der Fetus sich in einer guten Position befindet, so ist die 2-dimensionale Demonstration eines solchen Gesichtsdefekts für die Eltern nur schwer verständlich. Im Gegensatz zur 2D-Sonografie bietet die 3D-Oberflächendarstellung eine exakte Darstellung der Weichteile des fetalen Gesichts, wodurch Untersucher und werdende Eltern einen Gesichtsdefekt und dessen Ausmaß sehr wohl beurteilen können. Insbesondere mit der sog. HDlive-Technologie [15] lassen sich damit beeindruckende photorealistische Bilder eines Oberflächendefekts beim Ungeborenen erzielen ( $\odot$ Abb. 1 und 2). Durch die koronare Oberflächendarstellung von Schnittflächen des fetalen Gesichts gelingt auch der Nachweis einer isolierten Spalte im Bereich des harten oder weichen Gaumens ( 0 Abb. 3). Der Vorteil der 3-dimensionalen Diagnostik liegt aber nicht allein in der Oberflächendarstellung, sondern in den unterschiedlichen 3D-Darstellungsmodi, die eine detaillierte Beurteilung des fetalen Gesichts wie auch des Mund-Rachenraums ermöglichen. Hierzu zählen die triplanare Darstellung, bei der die senkrecht aufeinander stehenden Bildebenen (sagittale, axiale und koronare Schnittebene) gleichzeitig auf dem Monitor abgebildet werden ( $\bullet$ Abb. 3), der Tomografiemodus mit Darstellung paralleler Bildebenen, wie auch der Transparenzmodus, mit dem sich die einzelnen Gesichtsknochen isoliert beurteilen lassen [16-20]. Insbesondere die Kombination der einzelnen 3D-Darstellungsmodi gestattet eine subtile Fehlbildungsdiagnostik im Bereich des fetalen Gesichts mit Beurteilung von Stirn, Orbitae, Augen, Nase, Lippen, Kiefer, Kinn, Zunge und Gaumen.

Literatur bei den Verfassern 